\title{
Primary components in shaping koperasi masjid's participation level: Employing a principle component analysis approach
}

\section{Faktor utama pembentuk partisipasi anggota koperasi masjid: Pendekatan analisis komponen utama}

\author{
Fitriani $^{1}$, Sudiyo ${ }^{1}$, Dayang Berliana ${ }^{1}, \underline{\text { Evi Yuniarti }}^{2}$ \\ Department of Agribusiness, Faculty of Economy and Business, Politeknik Negeri Lampung \\ Department of Accounting, Faculty of Economy and Business Politeknik Negeri Lampung \\ Address: Jalan Soekarno-Hatta No.10, Rajabasa, Bandar Lampung, Lampung 35141 \\ E-mail: fitriani@polinela.ac.id \& eviyuniarti@polinela.ac.id
}

\begin{abstract}
Koperasi masjid present themselves as a part of muamalah through Sharia economic facilitation. This study was conducted to analyse the cooperative members' participation level in relation to the implementation of a cooperative business program. A survey using a case study approach was conducted at koperasi Masjid Hafshotul Iman, Masjid Taqwa and Masjid Darul Hikmah. The survey employed a purposive sampling method with the participation of the cooperative's management (chairman, secretary, and treasurer) and the masjid's members. Ten respondents were purposively chosen from each mosque and a total 30 respondents were acquired. The distributed questionnaire was a closed one, measured with a Likert scale. The results were analysed using factor analysis and the Principal Component Analysis approach (PCA). Based on the results of the factor analysis, the members' participation level in cooperative service can be classified into three primary factors. Some of the variables displayed a strong correlation with Factor 1, namely motivation, management performance, RAT performance, and supervisor performance. The second primary factor was formed by activeness in participating in cooperative activities. Lastly, the third primary factor encompassed three variables with a strong correlation, namely age, education, and membership duration.
\end{abstract}

Keywords: participation; motivation; cooperative; masjid; factor analysis; PCA

\begin{abstract}
Abstrak
Koperasi masjid hadir sebagai bagian muamalah melalui fasilitasi ekonomi secara syariah. Penelitian ini bertujuan untuk menganalisis tingkat partisipasi anggota koperasi masjid dalam pelaksanaan usaha dan program koperasi. Metode penelitian survei dengan pendekatan studi kasus, pada Koperasi Masjid Hafshotul Iman, Koperasi Masjid Takwa, dan Masjid Darul Hikmah. Penilaian tingkat partisipasi anggota koperasi masjid dilakukan dengan menggunakan kuesioner. Skala Likert digunakan untuk penilaian tingkat partisipasi anggota koperasi masjid dan variabel pembentuknya. Multivarite komponen utama Principal Component Analysis (PCA) digunakan untuk analisis data. Responden ditentukan secara purposive, meliputi representasi dari pengurus koperasi (ketua, sekretaris dan bendahara), dan anggota koperasi masjid yang masingmasing 10 orang dari setiap masjid, sehingga responden berjumlah 30 orang. Nilai koefisien communalities dari varabel yang diamati hasil analisis komponen utama (PCA) menunjukkan nilai keseluruhan variabel yang lebih besar dari 0.5. Nilai communalities tersebut menjadi landasan bahwa keseluruhan variabel yang digunakan memilliki hubungan yang kuat dalam membentuk faktor utama tingkat partisipasi anggota koperasi masjid. Variabel motivasi, kinerja pengurus, kinerja RAT dan kinerja pengawas memiliki korelasi yang kuat yang membentuk faktor utama pertama. Faktor utama kedua merupakan representasi dari dua variabel yang memiliki korelasi kuat antara variabel keaktifan dalam berpartisipasi dengan tingkat partisipasi anggota koperasi. Pada faktor ketiga terbentuk dari tiga variabel yang memiliki korelasi yang kuat di antara variabel umur, pendidikan, dan durasi/lama keanggotaan.
\end{abstract}

Kata kunci: partisipasi; motivasi; koperasi; masjid; analisis factor; PCA

\section{Introduction}

Koperasi masjid refers to an Islamic economic institution whose presence cannot be separated from religious, social, and state values. Beliefs in religious institutions and public influence in 
predominantly Muslim countries are arguably deep. The relationship between religion, state, and society in predominantly Muslim countries, like Indonesia and Malaysia, is a determinant factor in establishing institutional configuration, including economic institutions (Hassan 2013). Religious institutions play a significant role in providing services for society welfare (Hamayotsu 2007).

As an economic institution, koperasi masjid aims to empower the ummah's economic situations. It serves as a local economic institution which plays an important role as a part of a larger Sharia micro-finance institution. Strengthening local organisational and society empowerment programs through Sharia micro finance can be conducted by establishing strategic partnerships with mosques and other social institutions, like zakat or waqf institutions (Suzuki \& Pramono 2016, Nurhayadi 2016). Ummah's economic conditions become a main determinant in relation to achieving life quality and the capacity of a strong mu'min. As an economic institution, in order to improve ummah's welfare, koperasi masjid focus on optimalisation effort to utilise the ummah's and their surroundings' resources, which stimulates the establishment of new, profitable business ventures. Cooperatives play a crucial role in improving their members' welfare. The positive impact of the cooperative on their members can simply be observed from the members' need fulfilment. Cooperatives aim to improve the members' economic situations generally and the ummah's specifically. Koperasi masjid's success and reaped benefits depends on the members' cooperation and participation, from all members and ummah.

Based on data from jami' mosque in Bandar Lampung in May 2016, there are 647 mosques. Jami' refers to a large physical structure and there are a large number of jama'ah for salat al-jama'ah and Jumu'ah. Based on Islamic teachings, justice and welfare in economics should be derived from Islamic norms and ethics, so then the economic system faithfully follows Islamic Sharia (Kartika 2017). A cooperative's practices should not contradict Sharia laws; hence, muamalah transactions as a fundamental foothold are necessary (Fadlullah \& Mahmud 2017). Koperasi masjid aims to facilitate ummah in order to improve their economic conditions independently. The cooperative members' participation is the most essential factor in determining the cooperative's success and development. Unabridged member participation in each cooperative's productive activity becomes a core social capital in ensuring the cooperative's sustainability. The member's motivation and understanding of the cooperative's function and role is also necessary to achieve Muslim welfare.

The main factors determining the members' participation in cooperative activities include the members' knowledge level of the cooperative role, the cooperative's management service and business level, and both economic and non-economic benefits of the cooperative (Ayu et al. 2013, Hendra 2012, Syarbani 2010). The peak effectiveness of the members' participation can be achieved when the cooperative can fulfil their members' needs and wants; thus, the consumers' expectations and demands need to be aligned with the cooperatives' products and service. Cooperatives should be able to create economic benefits by delivering an efficient product and service, determining a competitive price, and stimulating the members through providing dividends based on their contributions (Aromatika 2011). The main factors that become priorities among Sharia financial service cooperatives generally comprise of the consumer's service and recruitment, billing, socialisation and promotion, the cooperative's financial health, blueprints, and the establishment of a cooperative network (Hasmayanti 2016). Koperasi masjid can play a role as the society economics' driving factor. This can be seen from the various economic activities around Al-Akbar Great Mosque in Surabaya as an example, encompassing production, distribution, and consumption activities (Suryani \& Faizah 2015).

A mosque's role in driving the ummah's economics has not completely achieved yet, because a mosque mainly focus on managing worship-related activities. As a consequence, mosques have not optimally shown their potential in relation to establishing its own economic power (Aisyah 2013). The cooperative members also have various participation levels among them. Differences in motivation, beliefs, sets of values, and benefits among the members determine their participation level. The cooperative members' participation in cooperative activities remain within the moderate or even low 
level of participation. This further causes a low level of trust in the cooperative. Hence, the expected business environment and cooperative's service level in terms of ummah economic empowerment have not reached the optimum level and this needs some improvement (Fitriani et al. 2017). This research aims to analyse the primary factors which create the cooperative members' participation level in relation to the cooperatives' organisational management and business within the framework of the cooperative members' economic empowerment in Bandar Lampung.

\section{Research Method}

This research was conducted using the survey method. The qualitative approach was employed through Primary Component Analysis (PCA). This research was conducted from May to November 2017 in some of the mosques in Bandar Lampung, Lampung Province. The respondents were selected purposively, encompassing cooperative management (core committee members: head, secretary, and treasury), mosque managerial staff involved in social activities, mosque caretakers, and the koperasi masjid's members. The cooperatives, which were decided as being research objects, were determined using the study case approach; Hafshotul Iman Mosque, Takwa Mosque, and Darul Hikmah Mosque. Ten respondents were selected from each mosque. The question list was compiled in the form of a closed survey, measured using the Likert scale. Grading was measured using four scales, namely extremely disagree (ED) for one point, disagree (D) for two points, agree (A) for three points, and extremely agree (EA) for 4 points.

The participation variable referred to the members' participation in every cooperative activity as stated on the cooperatives' memorandum/articles of association. The members' active participation in relation to performing their duties and obtaining their rights determines the realisation of the cooperative's objectives as an economic empowerment institution. Other variables in this research were age, education, membership, motivation, management, participants, RAT, and supervisors.

Tests on the data validity was conducted using validity and reliability tests. Next, the data analysis was conducted using the multivariate method of principal component analysis (PCA). This was based on the contributions from each original variable $\mathrm{X}_{1}, \ldots, \mathrm{X}_{5}$ to the primary component, then the original variable of $\mathrm{X}_{1} \ldots . \mathrm{Xp}$ was turned the linear combination into a new variable of $\mathrm{Y}_{1} \ldots . . \mathrm{Yp}$ :

$$
\begin{aligned}
& K_{1}=a_{11} x_{1}+a_{12} x_{2}+\ldots+a_{12} x_{2} \\
& K_{2}=a_{21} X_{1}+a_{22} x_{2}+\ldots+a_{2 z} x_{z} \\
& K_{p}=a_{p 1} X_{1}+a_{p 2} X_{2}+\ldots+a_{p p} X_{p} \text {, }
\end{aligned}
$$

Information:

$\mathrm{K}_{1}$ refers to First Primary Component (KU 1), variance $\operatorname{Var}\left(\mathrm{Y}_{1}\right)=\lambda_{1}$

$\mathrm{K}_{2}$ refers to Second Primary Component $(\mathrm{KU} 2)$, variance $\operatorname{Var}\left(\mathrm{Y}_{2}\right)=\lambda_{2}$

$\mathrm{K}_{\mathrm{z}}$ refers to nth Primary Component $(\mathrm{KU} \mathrm{z})$, variance $\operatorname{Var}\left(\mathrm{Y}_{\mathrm{z}}\right)=\lambda_{z}$

\section{Results and Discussions}

Based on the respondents' statistical recapitulation, most of them were around 46.7 years old. The youngest cooperative member was 26 years old and the oldest was 71 years old. It depicts that most of the respondents belong to the productive age group (15-65 years old). Moreover, the average education qualification level was 13.9 years or equals to Diploma I. Generally, the respondents obtained a significantly sufficient educational level to support the development of koperasi masjid. The average length of membership was 5.2 years, with the shortest membership period being 2 years and the longest one being 12 years. This shows that most members have been members for a while, and have therefore obtained a relatively adequate level of knowledge about the koperasi masjid's development and existence. The relationship bond between members and committee members within the cooperatives' institution is determined by the duration period of their interactions. The longer 
they interact, the more that bonding and bridging can be considered as productive social capital in the context of developing cooperative roles in the future (Fitriani 2015technology and markets. A lack of communication and coordination between the farmer and board member Gapoktan also cause ineffectiveness in Gapoktan performance. This study aims to identify the fusion process and consolidation of institutions Gapoktan become new economic institutions as agricultural cooperatives, also to discover the prerequisite conditions and the necessary support in the new cooperative institutions manifest in District Adiluwih. Methods RRA (rapid rural appraisal, Trisnanto et al. 2017).

The most important determinant in relation to the cooperative's success is its members' motivation to actively participate and directly contribute to every cooperative activity. Internal (obtained from members) and external strength when conducting activities wholeheartedly determines the social capital which guarantees the sustainability of social organisations.

Table 1.

\begin{tabular}{lcc}
\multicolumn{3}{c}{ Communalities values of all variables } \\
\hline Age & Initial & Extraction \\
Education & 1.000 & .721 \\
Membership & 1.000 & .671 \\
Motivation & 1.000 & .661 \\
Committee members & 1.000 & .946 \\
Participation & 1.000 & .870 \\
RAT & 1.000 & .942 \\
Supervisors & 1.000 & .984 \\
Extraction Method: Principal Component Analysis
\end{tabular}

Based on the Primary Component Analysis (PCA), the communalities value's coefficients of the variables have been displayed in Table 1. Overall communality values for all eight variables were recorded as being more than 0.5 point. Points higher than 0.5 meant that a variable recorded a highly correlated relationship. The more variables that record more than a 0.5 communality value, the better it is represented when establishing the primary factors. Next, the percentage of total variance can be examined from the values of Total Variance Explained (TVE). The TVE values from all of the variables can be seen in Table 2.

Table 2.

Total variance explained (TVE)

\begin{tabular}{|c|c|c|c|c|c|c|c|c|c|}
\hline \multirow{2}{*}{$\begin{array}{l}\text { Compo- } \\
\text { nent }\end{array}$} & \multicolumn{3}{|c|}{ Initial eigen values } & \multicolumn{3}{|c|}{$\begin{array}{c}\text { Extraction sums of squared } \\
\text { loadings }\end{array}$} & \multicolumn{3}{|c|}{$\begin{array}{l}\text { Rotation sums of squared } \\
\text { loadings }\end{array}$} \\
\hline & Total & $\begin{array}{c}\% \text { of } \\
\text { variance }\end{array}$ & $\underset{\%}{\text { Cumulative }}$ & Total & $\begin{array}{c}\% \text { of } \\
\text { variance }\end{array}$ & Cumulative & Total & $\begin{array}{c}\% \text { of } \\
\text { variance }\end{array}$ & $\underset{\%}{\text { Cumulative }}$ \\
\hline 1 & 4.153 & 46.141 & 46.141 & 4.153 & 46.141 & 46.141 & 3.950 & 43.885 & 43.885 \\
\hline 2 & 2.151 & 23.898 & 70.039 & 2.151 & 23.898 & 70.039 & 2.176 & 24.173 & 68.059 \\
\hline 3 & 1.429 & 15.877 & 85.916 & 1.429 & 15.877 & 85.916 & 1.607 & 17.857 & 85.916 \\
\hline 4 & .600 & 6.662 & 92.578 & & & & & & \\
\hline 5 & .494 & 5.487 & 98.065 & & & & & & \\
\hline 6 & .128 & 1.423 & 99.487 & & & & & & \\
\hline 7 & .046 & .513 & 100.000 & & & & & & \\
\hline 8 & $\begin{array}{l}3.2 x \\
10^{-17}\end{array}$ & $\begin{array}{l}3.5 x \\
10^{-16}\end{array}$ & 100.000 & & & & & & \\
\hline
\end{tabular}

Extraction Method: Principal Component Analysis

In Table 2, TVE refers to the percentage of total variance which can be explained by the factor variance. In the table, the eigen values for each factor have also been displayed. The components 
of the factors, which can be used to explain the total variance, all recorded an eigen value of more than 1. Furthermore, in Table 3, we can see that components 1, 2, and 3 obtained a cumulative value over $85.91 \%$, which signals that this model extracted 8 components/factors down to 3 components/ factors. Table 3 below further displays the matrix component.

Table 3.

Matrix component (MC)

\begin{tabular}{lrrr}
\hline \multirow{2}{*}{\multicolumn{1}{c}{ Variable }} & \multicolumn{3}{c}{ Component } \\
\cline { 2 - 4 } & $\mathbf{1}$ & $\mathbf{2}$ & $\mathbf{3}$ \\
\hline Age & .432 & -.114 & .722 \\
Education & .326 & .375 & -.652 \\
Membership & -.546 & -.295 & .525 \\
Motivation & .839 & -.423 & -.252 \\
Committee members & .889 & -.282 & -.028 \\
Participation & .339 & .873 & .256 \\
RAT & .969 & -.157 & .143 \\
Supervisors & .981 & .017 & .162 \\
\hline
\end{tabular}

\section{Extraction Method: Principal Component Analysis. a. 3 components extracted}

The correlation value from each variable has been displayed in Table 3 as the component matrix (MC). MC represents the correlation coefficient value and loading factor. The three factors result in a matrix loading factor whose values encompass the correlation coefficient between the variables and the 3 factors. Based on the values displayed in Table 3, the correlation coefficients that were less than 0.5 were recorded in all components (components $1,2,3$ ). Correlation values of more than 0.5 points were recorded in components 1,2 , and 3 . More than 0.5 values for the correlation coefficient were recorded altogether between motivation, RAT, committee members and supervisors. This result necessitates the further analysis of rotation using the marimax method. This method was an attempt to maximise the loading factor variance of each primary factor using orthogonal rotation. The high and strong correlations of the original variables can only relate to certain factors (whose correlation value is close to 1). Table 4 shows the tabulation of the rotation results using marimax method.

Table 4.

Rotated Component Matrix ${ }^{\mathrm{a}}$ (RCM)

\begin{tabular}{|c|c|c|c|}
\hline \multirow{2}{*}{ Variable } & \multicolumn{3}{|c|}{ Component } \\
\hline & 1 & 2 & 3 \\
\hline Age & .526 & .246 & -.619 \\
\hline Education & .127 & .193 & .786 \\
\hline Membership & -.373 & -.216 & -.689 \\
\hline Motivation & .891 & -.275 & .279 \\
\hline Committee members & .923 & -.057 & .123 \\
\hline Participation & .099 & .961 & .093 \\
\hline RAT & .983 & .134 & .017 \\
\hline Supervisors & .946 & .302 & .054 \\
\hline
\end{tabular}

Rotation Method: Varimax with Kaiser Normalization

Notes: a. Rotation converged in 6 iterations

In Table 4, it can be seen that the first primary factor (KU1) shows a strong correlation with a correlation value higher than 0.5 , including motivation, the committee members' performance, RAT performance, and the supervisor's performance. A value higher than 0.5 indicates that the rotation using the marimax method causes the loading factors to produce high and strong correlation values. 
The second primary factor (KU2) represents two variables with high and strong correlation values, particularly activeness in participation and the participation level of the cooperative members. Meanwhile, the third primary factor (KU3) consists of three variables with a strong correlation, including age, education, and duration of membership. The component plot in rotated space can be seen in the following figure.

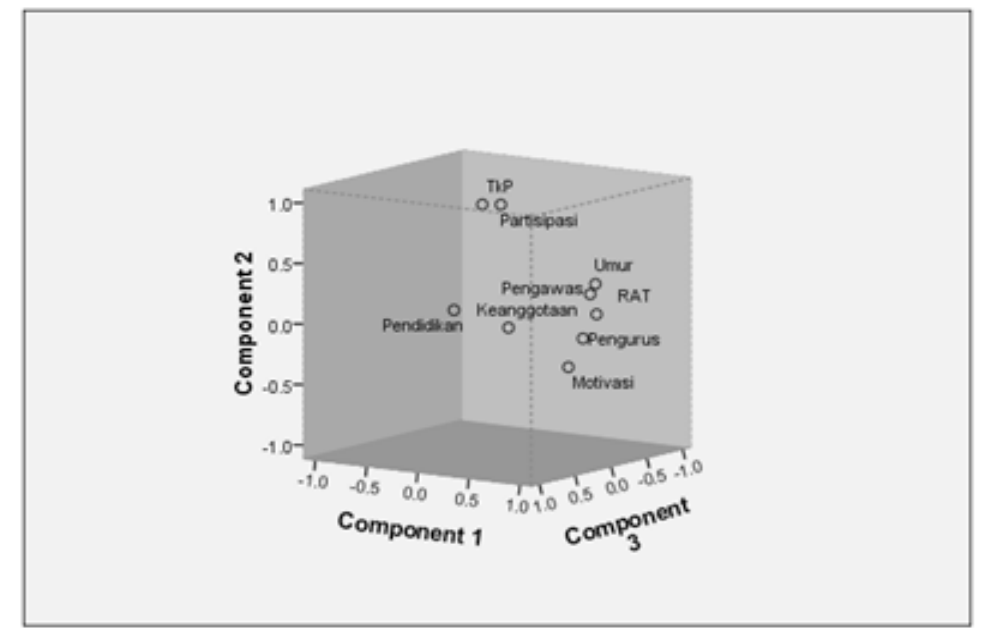

Figure 1.

Component plot in rotated space

The first primary factor represents the interdependence between motivation, management performance, RAT performance, and supervisor performance. It indicates the performance of the organisational management within the cooperatives, namely management, supervisors and RAT. The cooperative organisation pillar will be crippled if the three elements of the cooperative do not work in synergy. Cooperative performance is closely related to its members' motivation. Motivation is included among the cooperative pillars in the first primary factor. It shows that the performance of the cooperatives' management staff, RAT, and supervisors acts as a source of external motivation for the cooperative members related to participating in every service activity and at each step of organisational development. The first primary factor is also the key for cooperatives, in order for them to continue playing a sustainable role in achieving their goals as an economic organisation. A requirement for the proper operating of a cooperative are financial-managerial performance, while the supporting requirement of cooperative performance is a conducive business climate. Strengthening cooperative networks with strategic partners is key to the success of cooperatives in increasing their business capacity (Fitriani 2015)technology and markets. A lack of communication and coordination between the farmer and board member Gapoktan also cause ineffectiveness in Gapoktan performance. This study aims to identify the fusion process and consolidation of institutions Gapoktan become new economic institutions as agricultural cooperatives, also to discover the prerequisite conditions and the necessary support in the new cooperative institutions manifest in District Adiluwih. Methods RRA (rapid rural appraisal. Strengthening the aspects of Sharia supervision through improving the quality of human resources (including supervisors, administrators, and managers) can overcome the problem of Islamic cooperative's weak management (Yusuf 2016). The use of an integrated monitoring system accurately and appropriately should improve the operational processes of BMT (Baitul Mal Watamwil) as a Sharia microfinance institution (Nurhayadi 2016). Internal control structure and the management's knowledge of cooperative accounting (SAK ETAP) influences the cooperative's success (Yuniarti 2014, Fitriani et al. 2014).

The second primary factor is formed by activeness in participation and the participation level of the cooperative members. The members' participation in the cooperative is indicated by their active participation in the agenda of the cooperative. Members determine the success of member meetings, which are an important element in cooperatives. The success of member meetings acts as a control over the cooperative's direction as decided by the cooperative's management, closely related to the 
active involvement of the members in a cooperative member meeting. Cooperative management operations are carried out by cooperative managers, and are related to achieving both short- and long-term goals that need the support and active participation of cooperative members. The way that cooperative administrators accommodate the participatory suggestions of members to prepare cooperative work plans is necessary to pay attention to, even during the preparation of the budget and development plans. Moreover, members also actively participate in using the cooperative business services, such as purchasing their necessities in cooperatives, saving money in cooperatives, and using the business services/financial service offered by cooperatives. Based on the statements on the participation's activeness, the participation level of members can be measured. The categorisation of the members' participation level has been displayed in Table 5.

Based on the recapitulation results of the responses related to member participation, the categorisation of the cooperative members' participation level was conducted using the categorisation formula ((Nmax-Nmin)/range(7)). The results of the members' participation rate measurement were categorised as very low, low, less, moderate and high respectively (Table 5).

Table 5.

Koperasi masjid's member participation level

\begin{tabular}{lcccc}
\hline \multicolumn{1}{c}{ Category } & Range & Score & Respondents & $\mathbf{( \% )}$ \\
\hline Very low & $14-21$ & 0 & 3 & 10.00 \\
Low & $22-29$ & 1 & 9 & 30.00 \\
Less & $30-37$ & 2 & 8 & 26.67 \\
Moderate & $38-45$ & 3 & 7 & 23.33 \\
High & $46-53$ & 4 & 3 & 10.00 \\
& & & $\mathbf{3 0}$ & $\mathbf{1 0 0}$ \\
\hline
\end{tabular}

In Table 2, it can be seen that the members' participation in koperasi masjid is $56.67 \%$ in the nonoptimal category (between very low and less), while members who participated in the moderate and high category reached $43.33 \%$. This condition provides important information for the committee members of koperasi masjid related to continuing to motivate and mobilise their members' participation in every cooperative business service activity. Member participation, the leadership of the committee members, credit principles, and innovation ability have a positive and significant effect on the success of the cooperative business (Anggoro 2017, Rusyana et al. 2016). Hence, the cooperative's management needs to continue increasing the external motivation of their members through various programs and agendas which provide economic and non-economic benefits (Ayu et al. 2013, Hendra 2012, Syarbani 2010). Economic benefits can continue to be pursued by cooperatives through the efficient offering of goods and services, competitive pricing, and the stimulation of revenue from the remaining members based on their contributions. If cooperatives can meet the needs and desires of their members, then the better effectiveness in relation to the members' participation level can be achieved (Aromatika 2011). Members with a high participation level can get better economic benefits compared to members with a low and moderate level of participation (Martiani et al. 2016).

Age, education, and the duration of membership are the main variables included as the third primary factors and they recorded a strong correlation. The variables included in the third major factors represent the internal conditions of the cooperative members. This condition illustrates how cooperative members are closely related to their participation in cooperative activities. Age and educational background are important factors which drive individual decisions. Education provides an important insight for mosque management in relation to understanding and promoting mosque economic activities. Entrepreneurial orientation is an important factor that supports the involvement of mosque committees members in the economic activities between each mosque (Raflis et al. 2017). The members' education and training are closely related to one another and have a positive influence on the members' participation as cooperative owners and customers (Gunawan 2018). Meanwhile, 
the membership period shows the intensity and bonding of the members with the organisation. Membership duration is a driving factor for a sense of belonging and loyalty in the members. The role of cooperatives in building a people's economy continues to be tested. The key to the success and development of koperasi masjid highly depends on harmonious synergy between credible and accountable members and the cooperative's management. As an economic organisation, koperasi masjid (and other forms of cooperative) can play a broad role in dealing with the economic problems of their members.

Perhepi (2004) recommended that the care and attention of management staffs and cooperative members are important prerequisites for the sustainable development of cooperatives. Cooperatives are economic institutions with business foundations which pay attention to social interests in the form of their members' welfare. Therefore, the existence of koperasi masjid can be a place to practice muamalah conduct, because they are based on Islamic Sharia. Sharia principle itself becomes the most important foundation to ensure cleanliness in the income of the cooperative business. This principle is a prerequisite for Halal and the validity of the financing/investment agreement. This is the key to implement Islamic economics in the transaction process. Hence, the level of knowledge about Sharia principles within the koperasi masjid business needs to be continuously improved. The members' active participation in implementing Sharia transactions conducted by koperasi masjid is highly significant in ensuring the application of Sharia principles in muamalah. The application of Sharia in koperasi masjid in Bandung is apparent in the form of murabahah and musyarakah instruments, training Sharia cooperatives, Eid-al-Adha's sacrificial savings, Eid-al-Fitr's savings and other services (Wijayanti 2017).

Cooperative work as a community economic institution provides a broad economic multiplier. In addition to providing economic benefits by increasing socio-economic standards in the region, it also has the potential to increase the availability of local employment opportunities in the context of new sources of income in the region (Fitriani et al. 2017). A cooperative economic institution's existence is necessary to facilitate the growth rate of productive businesses in the real sector, especially among micro, small, and medium enterprises. The practice and role of Islamic leadership, member participation, and business performance are three important factors that stimulate the achievement of the members' prosperity in Sharia Financial Services Cooperative (KJKS) or Sharia Financial Services Unit (UJKS) in East Kalimantan (Mushofa et al. 2014).

Success in empowering mosque worshipers through cooperatives can explore, encourage, and motivate worshipers to be more independent and confident (Fadlullah \& Mahmud 2017). Moreover, a mosque is necessarily able to realise its function as an agent of transformation and empowerment for its worshipers, while manifesting its existence as more than just an amplifier of mahdhah worship by strengthening its efforts in social and economic empowerment (Zulfa 2015). Moreover, it is important for mosques to pay attention to fund-collection activities, because this generates a positive impact on society. Empowerment through mosque funds and its cooperatives is an excellent method to stimulate economic activities. Therefore, the role of the mosque is significantly important as a centre of unification and the triumph of Islamic society in various aspects of people's lives (Razak et al. 2014).

\section{Conclusion}

The results of the primary component analysis (PCA) shows that the communality value's coefficient via the variables is large (more than 0.5 ). Based on the communalities' values, it can be concluded that all of the variables have strong relationship to shaping the main factors in relation to the cooperative members' participation level. The first primary factors which showed a strong correlations were motivation, management performance, RAT performance, and supervisor performance. The second primary factors are the representatives of the two strongly correlated variables; activeness in participation and the cooperatives members' participation level. The third primary factors were created from three strongly-correlated variables, namely age, education, and the duration of membership. 


\section{References}

Aisyah S (2013) Membangun kekuatan ekonomi masjid. Jurnal Syari’ah 2 (2):51-62.

Anggoro ID (2017) The effects of members' participation, managerial personnel's leadership, and lending principles on the business success of rasa employee cooperative of republic of Indonesia (Ecri), Doro District, Pekalongan Regency. Jurnal Pendidikan dan Ekonomi 6 (1):311-318.

Aromatika DI (2011) Faktor-Faktor yang Mempengaruhi Partisipasi Anggota Pada KUD Makmur Jaya Kecamatan Jekulo Kudus. Universitas Negeri Semarang.

Ayu I, Sugiastini F, \& Yuliarmi NN (2013) Pengaruh partisipasi anggota terhadap keberhasilan koperasi serba usaha di Kota Denpasar. E-Jurnal EP Unud 4:210-219.

Fadlullah ME \& Mahmud MA (2017) Pemberdayaan ekonomi jama'ah masjid melalui koperasi. Jurnal LISAN 9 (2):361-382.

Fitriani (2015) Gapoktan capacity institutionalization through farmer cooperative. Masyarakat, Kebudayaan dan Politik 28 (2):63-69. https://doi.org/http://dx.doi.org/10.20473/mkp. V28I22015.65-71.

Fitriani F, Sudiyo, \& Berliana D (2017) Tingkat Partisipasi Anggota "Koperasi Masjid" dalam Memberdayakan Ekonomi Ummat di Kota Bandar Lampung. Seminar Nasional Pengembangan Teknologi Pertanian (307-312). Politeknik Negeri Lampung.

Fitriani, Sutarni, Haryono D, Ismono H, \& Lestari DAH (2017) Pertanian perdesaan Lampung: Peluang dan tantangan. JoFSA (Journal of Food System \& Agribusiness) 1 (2):43-52.

Fitriani, Sutarni, Yuniarti E, \& Fatih C (2014) Koperasi pertanian sebagai solusi persoalan ekonomi masyarakat pertanian perdesaan di Kec. Adiluwih, Kab. Pringsewu. LPPM Universitas Lampung (ed), Pemberdayaan Masyarakat melalui Pengembangan Ekonomi Kreatif (1-10). Bandar Lampung: LPPM Universitas Lampung.

Gunawan U (2018) Pengaruh faktor pendidikan anggota terhadap partisipasi sebagai pemilik dan pelanggan (Studi kasus pada Kojamas Al-Muttaqien, Bandung). Coopetition 9 (Mei):1-14.

Hamayotsu K (2007) Kikue Hamayotsu. In Religion and the Politics of Development This (155-176).

Hasmayanti (2016) Analisis penilaian kesehatan koperasi jasa keuangan syariah berbasis masjid (Studi kasus KJK Syariah BMT At-Taqwa Kemanggisan Jakarta Utara. Jurnal Riset Manajemen dan Bisnis 1 (2):163-170.

Hassan R (2013) Power and Piety: Religion, State and Society in Muslim Countries (No. 16).

Hendra G (2012) Pengaruh Partisipasi Anggota Terhadap Kinerja Pengurus Kud Langgeng Desamarsawa Kecamatan Benai Kabupaten Kuantan Singingi. Universitas Islam Negeri Suska Riau.

Kartika D (2017) The Point of Intersection and Synergy Islamic Economics and People Economy. Proceeding of 7th Annual International Conference (98-106). Banda Aceh: Syiah Kuala University.

Martiani D, Lestari DAH, \& Murniati K (2016) The level of participation, income structure, and prosperity of Tani Surya Sekawan Cooperative's members in Banyuwangi Village, Banyumas District, Pringsewu Regency. Jurnal Ilmu-Ilmu Agribisnis 4 (2):189-191.

Mushofa A, Mursinto D, \& Anam S (2014) Influence of the Islamic leadership to participation of the members, business performance and prosperity of the members of syari'ah financial service cooperative in East Kalimantan Province. European Journal of Business and Management 6 (38):217-226.

Nurhayadi Y (2016) Comprehensive supervision for operational soundness of sharia financial service cooperatives. HUMAN FALAH: Jurnal Ekonomi dan Bisnis Islam 2 (Januari):113-135. 
Raflis A, Omar C, Yahya M, Hussin M, \& Fidlizan M (2017) Mosque economic activities and entrepreneurial orientation: A preliminary study. International Journal of Accounting Finance and Business (IJAFB) 2 (6):50-56.

Razak AA, Hussin MYM, Muhammad F, \& Mahjom N (2014) Economic significance of mosque institution in Perak State, Malaysia. Kyoto Bulletin of Islamic Area Studies 7 (7):98-109.

Rusyana, Fathoni A, \& Warso MM (2016) Pengaruh partisipasi, komitmen dan kemampuan inovasi anggota terhadap arah pengembangan koperasi (Studi empiris pada Koperasi Primer S-22 Kodam IV Diponegoro Kota Semarang). Journal of Management 2 (2).

Suryani H \& Faizah SI (2015) Peran masjid sebagai penggerak roda perekonomian masyarakat. JEST 2 (5):387-399.

Suzuki Y \& Pramono S (2016) Islamic microfinance and poverty alleviation program: Preliminary research. SHARE 5 (1):63-82.

Syarbani H (2010) Analisis pengaruh partisipasi santri komitmen dan kemampuan berinovasi terhadap kinerja koperasi pondok pesantren di Kota Semarang. Economica 1 (Nopember):133-148.

Trisnanto TB, Fitriani, \& Fatih C (2017) Membangun modal sosial pada gabungan kelompok tani. Masyarakat, Kebudayaan, dan Politik 30:59-67.

Wijayanti N (2017) Faktor-faktor yang mempengaruhi sisa hasil usaha pada koperasi syariah di Kabupaten Karanganyaro Title. Jurnal Keuangan dan Perbankan 13 (2):110-119.

Yuniarti E (2014) Effectiveness of the Application of Internal Control Structure, Capital and Management Knowledge about Cooperative Accounting (SAK ETAP) toward cooperative performance. ESAI 8 (1):1-12.

Yusuf B (2016) Analisis tingkat kesehatan koperasi syariah. Esensi: Jurnal Bisnis dan Manajemen 6 (1):101-112. https://doi.org/10.15408/ess.v6i1.3124.

Zulfa M (2015) Transformasi dan pemberdayaan umat berbasis masjid: Studi pada Masjid Nurussa'adah Salatiga. INFERENSI: Jurnal Penelitian Sosial Keagamaan 9 (1):257-278. https://doi.org/https://doi.org/10.18326/infsl3.v9i1.257-278. 